\title{
Nicolae Preda, Rânduiala rugăciunii ce se face după ieșirea sufletului din trup, conform Psaltirii de la 1818, Edit. Basilica, București, 2015, 352 p.
}

Părintele Diacon Lector Dr. Nicolae Preda este licențiat „Magna cum laude” în cadrul Facultăţii de Ştiinţe Bisericeşti Orientale a Institutului Pontifical Oriental de la Roma, fiind doctor în Ştiinţe Liturgice al Institutului

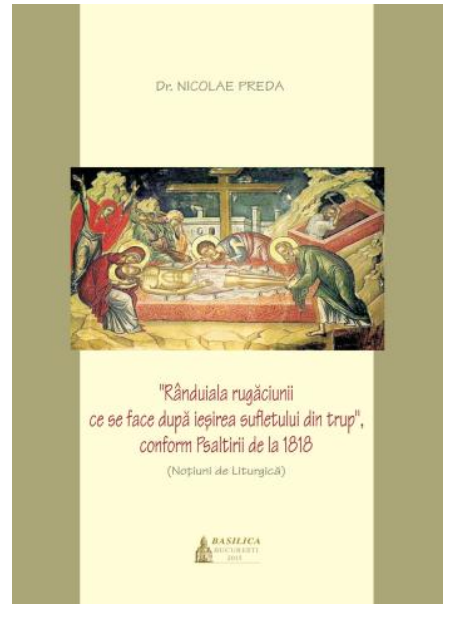

Pontifical Oriental de la Roma, cu o lucrare intitulată Preghiere salmiche di autori vari secondo il codice "Vaticano Greco 783" (ff. 1-96r) $)^{1}$, în prezent activând la Facultatea de Teologie Ortodoxă „Justinian Patriarhul" din București. Părintele Preda este prezent în lumea academică cu numeroase studii și cărți în domeniul Teologiei liturgice.

Cartea propusă spre lectură, Rânduiala rugăciunii ce se face după ieșirea sufletului din trup, conform Psaltirii de la 1818, publicată la

${ }^{1}$ Nicolae PREDA, Preghiere salmiche di autori vari secondo il codice "Vaticano Greco 783” (ff. 1-96r) (studio liturgico), în „Colecţia liturgică”, 4, București, Edit. Granada, 2016, 504 p.

2 O listă incompletă a publicațiilor părintelui Preda se poate consulta online: https://unibuc.academia.edu/nicolaepreda/ (accesat 13.02.2021). 
editura Basilica în 2015, reprezintă rodul continuării preocupărilor din timpul studiilor doctorale ale autorului.

Dacă titlul îl face pe cititor să se gândească că are în mâini o carte ce tratează o (singură) rugăciune, parcurgând cele 352 de pagini ale volumului, observând cele 80 de manuscrise menționate în studiu, urmărind cele 170 de volume în română, greacă, italiană, franceză, engleză, germană și rusă - cât însumează bibliografia acesta va constata că rugăciunea este pusă într-un context, într-o rânduială de slujbă riguros analizată. Cuprinsul succint îi poate crea iarăși cititorului impresia că are de a face cu o lectură facilă, impresie ce este spulberată de cele 2521 de note de subsol care însoțesc studiul. Concluziile însumează, în cazul de față, aproximativ jumătate din volumul cărții.

Părintele Preda ,ține să precizeze"3, după cum se exprimă în numeroase locuri din carte, că punctul de plecare în alcătuirea prezentului studiu 1-a reprezentat un text dactilografiat al Părintelui Profesor Boitan Florin: „Rînduiala rugăciunii ce se face după ieșirea sufletului din trup", pe care părintele 1-a îmbogățit și publicat într-o formă riguroasă.

Cartea scoate la lumină primul document ce conține „Rânduiala rugăciunii ce se face după ieșirea sufletului din trup”, și anume Psaltirea tipărită în anul 1818 cu litere chirilice la Chișinău, retipărită în două rânduri, în 1857 și 1907. Introducerea este plină de mărturii istorice despre cele trei ediții ale Psaltirii. Rânduiala conţine binecuvântarea de început, rugăciunile trisaghionului, troparele specifice celor adormiţi, ectenie, canon cu opt pesne la finalul căruia se întâlnește rugăciunea fundamentală a rânduielii (Pomenește, Doamne, Dumnezeul nostru...).

Autorul consideră ediția textului una semi-diplomatică, deoarece, ,pentru claritatea acestuia am evitat redarea valorilor fonetice (adică a corespondenței în alfabetul latin) ale anumitor

${ }^{3}$ Expresia ,țin să precizez" apare de 33 de ori în text: p. 5 n. 1, p. 62, p. 144 n. 1594 , p. 153 , n. 1632 , p. 154 , p. 160 , p. 185 n. 1820 , p. 197 n. 1912, p. 202, p. 207 n. 1952 , p. 212 n. 1990 , p. 220 , p. 227 , p. 228 , p. 233 , p. 240 n. 2132 , p. 249 , p. 260 , p. 267 , p. 272 , p. 275 , p. 283 , p. 287 n. 2397 , p. 291 , p. 291 n. 2415 , p. 294 , p. 296, p. 301 , p. 308 , p. 312 , p. 313 n. 2513 , p. 314 n. 2518 , p. 319. 
litere (slove), pentru a nu îngreuia fie chiar şi o primă lectură a textului, dar şi pentru a evita o înșiruire interminabilă de note de subsol" (p. 58). Modul de transliterare al caracterelor slavone în alfabet latin este mai apoi redat, precizându-se și faptul că s-au înlocuit ,chiar şi unele cuvinte (arhaisme) direct în text, schimbările fiind indicate de fiecare dată în notele de subsol" (p. 61).

Textul Rânduielii este disecat și analizat în paralel în cele trei ediții luate în considerare. Din analiza textului cuvânt cu cuvânt nu lipsesc trimiterile scripturistice la care face referință sau aluzie textul Rânduielii.

Capitolul text propus spre introducere în cărţile de cult reprezintă varianta diortosită a rânduielii analizate, aranjată pentru a îmbogății cărțile de cult. Un prim pas făcut este introducerea doar a rugăciunii Pomenește, Doamne, Dumnezeul nostru... în Panihidă și, mai apoi, în Molitfelnic ${ }^{5}$. Chiar dacă s-a considerat inoportună prezența întregului canon din Rânduială, introducerea rugăciunii este o dovadă actuală a maleabilității cărților de cult al căror cuprins poate varia, acesta putând fi îmbogățit, dar, la fel de bine, și restrâns. Fenomenul de îmbogățire nu trebuie să reprezinte doar introducerea unor rânduieli noi în defavoarea unora vechi care au intrat în desuetudine ${ }^{6}$, ci și introducerea spre uzul larg a unor rânduieli care au avut o răspândire locală, dar, în contextul pastoral actual, au o aplicabilitate generală.

În partea intitulată Concluzii întâlnim un capitol structurat pe mai multe subcapitole. Un subcapitol amplu dezvoltat îl reprezintă reflecțiile autorului asupra structurii Rânduielii. Partea introductivă este analizată, iar prezența rugăciunii Impărate ceresc este critic observată. Trisaghionul pentru cei morți este atât o denumire, cât și o rânduială ce primește multă atenție din partea autorului, care evidențiază cititorului și formulare ,inedite” ale Abației din

$4 * * *$ Panihida, Edit. Institutului Biblic și de Misiune al Bisericii Ortodoxe Române 2016, p. 198.

5 ***Molitfelnic, București, Edit. Institutului Biblic și de Misiune Ortodoxă, 2019, p. 400.

${ }^{6}$ A se vedea Robert F. TAFT, „Comparative Liturgy. Years after A. Baumstark”, în Worship 73/1999, p. 521-541. 
Grottaferrata. Rugăciunea Dumnezeul duhurilor... este un alt element de analiză al Părintelui Preda, căruia îi dedică numeroase pagini ${ }^{7}$. Canonul, rugăciunea, troparele de la sfârșit, precum și otpustul sau apolisul sunt analizate în subcapitole separate. Litia mică pentru cei morți este o altă rânduială pe care autorul o acoperă în studiul său.

Părintele Nicolae Preda dă dovadă de modestie academică afirmând, spre exemplu, următoarele: ,întorcându-ne la Rânduielile inmormântării, consider că precizările manuscriselor indicate în precedenţă nu ne permit nicidecum să forţăm semnificaţia în sine a acestora, în sensul că nu pot servi drept fond unor simple supoziţii de genul: în vechime Rânduiala înmormântării ar fi fost unită cu Sfânta Liturghie; realitate care, pe de altă parte, nu poate fi nici contestată. Afirmația mea se rezumă doar la a evidenţia faptul că formularele liturgice în cauză nu amintesc nimic în acest sens" (p. 173).

Ținând cont de numărul mare de note de subsol și de complexitatea acestora, precum și de multiplele citate în mai multe limbi și scrieri, textul are o redactare îngrijită, în care autorul a investit multă atenție și foarte mult timp, dovadă fiind și numărul mic de scăpări de redactare întâlnite în versiunea publicată. ${ }^{8}$

Urmărind notele de subsol, observăm că, probabil, din dorința de a fi exhaustiv, autorul repetă definiția unor termeni liturgici. De exemplu, explicația cuvântului apolis compare în două

${ }^{7}$ Interesul autorului pentru această rugăciunea a dat naştere mai multor articole: Nicolae PREDA, ,The prayer «God of the spirits» a brief historical and liturgical analysis", în Ephemerides Liturgiae 132/2018, p. 220-232; „The prayer «God of the spirits» - short textual analysis”, în Icoana Credinței, 4/2018, p. 48-62; „Rugăciunea «Dumnezeul duhurilor» (scurtă analiză textuală), în Ortodoxia 1/2019, p. 48-65; „The prayer "God of the spirits» (an expression that disappeared from liturgical structures: «in Abraham's, Isaac's and Jacob's bosoms»)", în International Journal of Theology, Philosophy and Science, 1/2017, p. 36-44; „Rugăciunea «Dumnezeul duhurilor» (o expresie care a dispărut din structurile liturgice: «în sânurile lui Avraam şi ale lui Isaac şi ale lui Iacov»)", în Studia Doctoralia Andreiana, 1/2018, p. 56-77.

8 Am reușit să identific doar cinci cuvinte cu scriere defectuoasă de care, într-o eventuală republicare a cărții, se poate ține cont: p. 192 ,importatntă”, p. 268 „mrormânt”, p. 279 „Constaninopol”, p. 300 ,,pimul”, p. 308 ,,înr-un”. 
locuri, p. 205 n. 1944 și p. 276 n. 2334. Dacă prima dată definiția este preluată din Dicţionarul enciclopedic al soților Braniște ${ }^{9}$, în cea de-a doua apare în plus definiția din Dictionnaire grec-français des noms liturgiques ${ }^{10}$. Rămâne discutabilă necesitatea prezenței acestor definiții ale unor termeni bine cunoscuți de cei care ar fi interesați de acest studiu de specialitate.

În concluziile finale autorul își reafirmă intenția inițială, mărturisită în introducere, aceea de a scoate la lumină pur și simplu textul acestei Rânduieli de slujbă, care, într-un final, s-a concretizat în prezentul studiu, reușind să aducă înaintea cititorului mai mult decât s-a intenționat la început. De asemenea, autorul își exprimă dorința ca ,această Rânduială de slujbă, care are în structura ei şi numeroase elemente «inedite», să fie luată în considerare în mod corespunzător şi să fie așezată la loc de cinste".

Așadar, printr-un studiu riguros al unei rânduieli trecute cu vederea, Rânduiala rugăciunii ce se face după ieșirea sufletului din trup, Părintele Nicolae Preda reușește să contribuie la sporirea cunoaşterii tezaurului liturgic de care dispune Ortodoxia şi să persuadeze factorii decidenți ca, în primă etapă, să introducă rugăciunea din Rânduială în cărțile de cult oficiale. Așteptăm ca, în viitor, întregul canon să fie pus la dispoziţia slujitorilor şi credincioșilor Bisericii Ortodoxe Române, ca noi, cei vii, care vom fi rămas, să-i purtăm în rugăciuni pe cei plecaţi dintre noi. Domnul Dumnezeul duhurilor şi a tot trupul (cf. Num. 27, 16) să rânduiască în Biserica Sa oameni care să învie astfel de rânduieli și, în Duhul Sfânt, să compună altele, după nevoile timpurilor noastre.

Drd. Mihai Răducă Universitatea București

9 Ene Branişte, Ecaterina BranişTE, Dicţionar enciclopedic de cunoştinţe religioase, Caransebeş, Edit. Diecezană, 2001, 42-43.

${ }^{10}$ Léon Clugnet, Dictionnaire grec-français des noms liturgiques en usage dans l'Église grecque, Paris, A. Picard et fils, 1895, p. 18 